\title{
A PRACTICAL METHOD FOR SCREENING FOR $\beta$-GALACTOSIDASE SECRETING MICROBIAL COLONIES
}

\author{
Eriana S. Barreto; Daison O. Silva: Flavia M. Lopes Passos* \\ Departamento de Microbiologia, Bioagro, Universidade Federal de Vicosa, MG, Brasil
}

Submitted: August 06, 1999; Returned to authors for corrections: February 04, 2000; Approved: March 28, 2000

\begin{abstract}
Microbial colonies were replicated on $\mathrm{YNB} \otimes$ agar plates overlaid with soft agar containing the glucoseoxidase/peroxidase (BIOTROL $\AA$ ) system. The pink color developed around the colonies was the result of the reaction of the glucose generated by the extracellular hydrolysis of lactose by $\beta$-galactosidase, indicating secretion of this enzyme. This method proved to be very convenient for testing hundreds of colonies grown on agar plates for $\beta$-galactosidase secretion by microbial cells.
\end{abstract}

Key words: $\mathrm{BIOTROL}{ }^{\circledR}, \beta$-galactosidase

Strains of the species Kluyveromyces lactis are used commercially for production of $\beta$-galactosidase. This enzyme hydrolyses milk lactose into its constituents glucose and galactose. It is used in the commercial preparation of processed milk with low lactose content (2).

Similarly to bacteria, but not to filamentous fungi, K. lactis does not secrete $\beta$-galactosidase into the culture medium (5). To obtain a more efficient strain for the industrial production of $\beta$-galactosidase, millions of colonies of Kluyveromyces lactis mutants should be screened for secretion of this enzyme. The available methods to detect extracellular $\beta$-galactosidase require the growth of individual isolated colonies in liquid media, limiting the screening procedure (4). Thus, a new tecnique was developed to detect extracellular $\beta$-galactosidase activity, based on the reaction of glucose oxidase and peroxidase in the BIOTROL $®$ (Merck) system. The method described here was developed based on the procedure described by Cabib and Duran (3) and Belda and Zarate (1).

After growth, microbial cells were harvested, suspended in $10 \mathrm{ml}$ 0.95\% saline and plated on YNB agar (Bacto $\AA /$ Difco) plus $2 \%$ lactose. The plates were incubated for two to seven days at $30^{\circ} \mathrm{C}$. Replica plates were prepared with YEPL $(1 \%$ yeast extract, $2 \%$ peptone and $2 \%$ lactose) and $2 \mathrm{X}$ YNB with $2 \%$ lactose and incubated again at $30^{\circ} \mathrm{C}$ for two to seven days. Following incubation, an overlay of $0.45 \%$ agarose containing the glucose oxidase and peroxidase (BIOTROL $\AA$ ) reagent, in a proportion of 7:3(V/V), was added to each plate. The presence of glucose in the media, resulting from lactose hydrolysis by extracellular $\beta$-galactosidase, was detected by the pink color around the colonies.

Fig. 1 shows $A$ niger, a natural secretor of $\beta$-galactosidase, with a positive result, and other organisms with negative results.

The test principle is:

Glucose $+\mathrm{O}_{2}+\mathrm{H}_{2} \mathrm{O} \leftrightarrow$ Gluconic acid $+\mathrm{H}_{2} \mathrm{O}_{2}$.

Hidrogen peroxide resulting in this reaction reacts with 4aminoantipyrine and 4-hydrobenzoic acid, in the presence of peroxidase, liberating the dye N-4-antipyril-p-benzoquinoneimine. The amount of the dye formed is directly proportional to glucose concentration. This technique proved to be fast, since the reaction occurs in less than 30 minutes. Hundred colonies per plate can

\footnotetext{
* Corresponding author. Mailing address: Departamento de Microbiologia, Universidade Federal de Viçosa, CEP 36570-000, Viçosa, MG, Brasil. FAX (+5531) 899-2864. E-mail: flpassos@mail.ufv.br
} 
be tested simultaneously. However, this test is appropriated to detect glucose resulting from extracellular $\beta$-galactosidase, but not from other extracellular hydrolases, such as invertase, since sucrose, but not lactose, reacts with the coupled enzyme BIOTROL $®$ system.

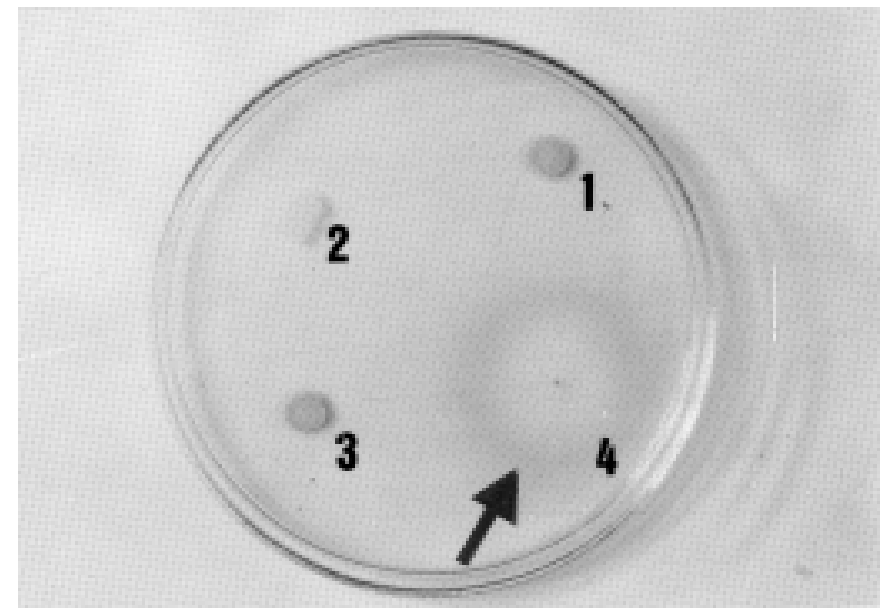

Figure 1. Secretion of $\beta$-galactosidase in $2 \mathrm{X}$ YNB (Difco) plus $2 \%$ lactose.1Wild type Kluyveromyces lactis; 2 - K. marxianus; 3 - mutant $1.0 \mathrm{mg} / \mathrm{ml}$ geneticin resistent 4-Aspergillus niger. The arrow indicates the pink halo around the colony.

No report was found describing a differential agar like this one, where an enzyme system with a chromophore to detect extracellular hydrolysis products of lactose is used. This is a convenient altenative to indicate extracellular $\beta$-galactosidase on agar plates to detect $\beta$-galactosidase secreting microbial cells. This technique has been used in our laboratory to select Saccharomyces cerevisiae that has been transformed with a secretion vector containg the lac $\mathrm{Z}$ gene.

\section{RESUMO}

\section{Método prático de triagem de colônias de microrganismos secretoras de $\beta$-galactosidase.}

Colônias microbianas foram replicadas na superfície de ágar $\mathrm{YNB}{ }^{\circledR}$ contendo lactose, recoberta com uma camada de ágar semi-sólido contendo o sistema glicose-oxidase/peroxidase (BIOTROL $®)$. Coloração rosa foi desenvolvida ao redor das colônias como resultado da reação de glicose gerada pela hidrólise extracelular de lactose pela $\beta$-galactosidase, indicando secreção da enzima pelo microrganismo.

Palavras-chave: $\mathrm{BIOTROL} \AA, \beta$-galactosidase

\section{REFERENCES}

1. Belda, F.; Zárate, V. Isolation and characterization of Schizosaccharomyces pombe fragile mutants. Yeast, 12: 555-564, 1996.

2. Bonekamp, F.J.; Oosterom, J. On the safety of Kluyveromyces lactis - a review. Appl. Microbiol. Biotechnol. , 41: 1-3, 1994.

3. Cabib, E.; Duran, A. Simple and sensitive procedure for screening yeast mutants that lyse at nonpermissive temperatures. J. Bacteriol., 124: 1604 1606, 1975.

4. Rasouli, I.; Kulkarni, P.R. Enhancement of $\beta$-galactosidase productivity of Aspergillus niger NCIM-616. J. Appl. Bacteriol., 77: 359-361, 1994.

5. Sheetz, M.; Dickson, R.C. LAC4 is the structural gene for $\beta$-galactosidase in Kluyveromyces lactis. Genetics, 98: 729-745, 1981. 